\title{
Investigation of stability of colorant powders extracting from Japanese purple sweet potato (Ipomoea batatas (L.) Poir)
}

\author{
Phan Nguyen Quynh Anh, Le Thi Hong Nhan
}

\begin{abstract}
The stability of colorant powders from Japanese purple sweet potato (Ipomoea batatas (L.) Poir) harvested in Vinh Long province was investigated. The colorants were formed from extracting solutions which were adjusted to $\mathrm{pH}$ of 6 , 5,4 and 3 before converted to powder matrix. They had red-purple color and contained anthocyanin concentration of about $32 \mathrm{mg} / \mathrm{g}$. The IC50 inhibitory concentration of the neutral powder was 292.7 $\mu \mathrm{g} / \mathrm{mL}$, whereas the IC50 of $\mathrm{pH} 3$ powder was 484 $\mu \mathrm{g} / \mathrm{mL}$, which antioxidant activity decreased by increasing of acidic media clearly. Stability of appearance colors, anthocyanin content, polyanthocyanin index and antioxidant capacity were investigated and they depended on storing conditions (temperature and radiation) and $\mathrm{pH}$ media. To avoid denaturation of anthocyanin content, the pigment should be stored in the dark and at low temperature $\left(10{ }^{\circ} \mathrm{C}\right)$. The acidic media could preserve the colorant powder by protecting anthocyanins, but it reduced the biological property of the pigment.
\end{abstract}

Index Terms - purple sweet potato, anthocyanin, stability, antioxidant.

\section{INTRODUCTION}

$\mathrm{N}$ owadays, the demand for natural colors is increasing very much due to the increased awareness of therapeutic and medicinal properties and their benefits of them. Anthocyanin is one of natural coloring agents which are quite common,

Manuscript Received on October 17th, 2016, Manuscript Revised April 07th, 2017

This research is funded by Ho Chi Minh City University of Technology -VNU-HCM, under grand number T-KTHH-201650.

Phan Nguyen Quynh Anh, Le Thi Hong Nhan - Ho Chi Minh City University of Technology, VNU-HCM. Email: pnqanh@hcmut.edu.vn soluble in water and found in red/purplish fruits and vegetables. Anthocyanin pigments take their color from the range of red, purple, or blue, depending on their $\mathrm{pH}[1,2]$. Anthocyanins have a lot of benefits for the health as anti-inflammatory, antioxidant, reducing the risk of heart disease and various cancers [1]. Besides, anthocyanin is representative of important antioxidants for shown a higher antioxidant activity than vitamin $\mathrm{C}$ and vitamin E [3, 4]. Furthermore, anthocyanins, either individually or combined, also have the ability to enhance the activity of vitamin $\mathrm{C}$ and some other flavonoids [5].

However, the applicability of anthocyanins in foods is limited because the conditions during colorants manufacturing and processing (light, oxygen, as well as heating treatment), can influence the stability of the colorants' bioactive compounds $[6,7]$. Factors affecting the reliability of anthocyanins may be mentioned as $\mathrm{UV}, \mathrm{pH}$, temperature, moisture, sugar, the presence of oxygen, enzymes, as well as the presence of ascorbic acid, sulfur dioxide, salt sulfite, metal ions, copigmentation and the main structure of anthocyanins [8].

Japanese purple sweet potato from Binh Tan (Vinh Long) is very popular in the Southern of Vietnam. In the first stage of the project, the authors studied on optimal condition for extracting the colorant solution [9]. The colorant solutions had high concentration of anthocyanins. However, the color liquid is quite not convenient comparing to powder form. In this paper, the project was continued with preparing the powder forms from extracting solutions and evaluating the characteristics as well as stability. 


\section{EXPERIMENTS}

Japanese purple sweet potato was harvested from Binh Tan district (Vinh Long province, Vietnam) in August, 2014. The sweet potato should be steamed, sliced and dried without direct sunlight and then was ground to fine powder. Potato powder was extracted with EtOH 60, material/solvent ratio of $1 / 5(\mathrm{~g} / \mathrm{ml})$, at $65{ }^{\circ} \mathrm{C}$ and for $40 \mathrm{mins}$ to collect liquid extract with anthocyanin concentration of about $110 \mathrm{mg} / \mathrm{L}$ [9]. The $\mathrm{pH}$ of the liquid extract was adjusted to $3,4,5$ and 6 by citric acid. Then their solvent was removed by using a rotating evaporator under a vacuum condition to collect powders (samples were marked as pH3, pH4, pH5, pH6 and No for control sample).

Visual appearance, physical properties, solubility, and heavy metal content were determined by the standard procedures for food pigments. Antioxidant activity was conducted by a reaction with the free radical DPPH (1,1-diphenyl2-picrylhydrazyl) $[10,11]$ and using vitamin $\mathrm{C}$ as a control.

To investigate stability, the colorant powders were stored in white/brown bottles (to simulate light/dark storing conditions) at desired temperatures $\left(10,30,45\right.$ and $\left.55^{\circ} \mathrm{C}\right)$. Accelerated aging test parameters are based on the Q10 thermodynamic temperature coefficient. Based on the accelerated stability results, the actual stability of the colorant may be predicted in normal storing condition [12]. By times, each sample was taken and dissolved with ethanol and the characteristics (concentration of anthocyanins and polyanthocyanin index) were conducted based on the $\mathrm{pH}$ differential method [13, 14]. The stability was calculated by the percentage of remained anthocyanin concentration.

\section{RESULTS AND DISCUSSIONS.}

In many publications, the researchers found that color hue and stability of the anthocyanin solutions could be changed by $\mathrm{pH}$ condition and the anthocyanins are stable in acidic media $[15,16]$. That is the reason which the $\mathrm{pH}$ of the extracting solutions was set as acidic media. After removing solvent, powdered colorants were formed and anthocyanin concentration of about $32 \mathrm{mg} / \mathrm{g}$ $(0.32 \%)$. Different $\mathrm{pH}$ condition was not affected the visual color of the powders and were red- purple color. The yield of colorant powder production was about $32 \%$. All powders had ash, $\mathrm{As}, \mathrm{Cd}$ and $\mathrm{Pb}$ contents of $3.58 \%, 0.00001 \mathrm{ppm}$, $0.001 \mathrm{ppm}$ and $0.001 \mathrm{ppm}$, respectively and satisfied standards for the food colorant (accordance with Decision No.46/2007/QD-BYT of the Ministry of Health).

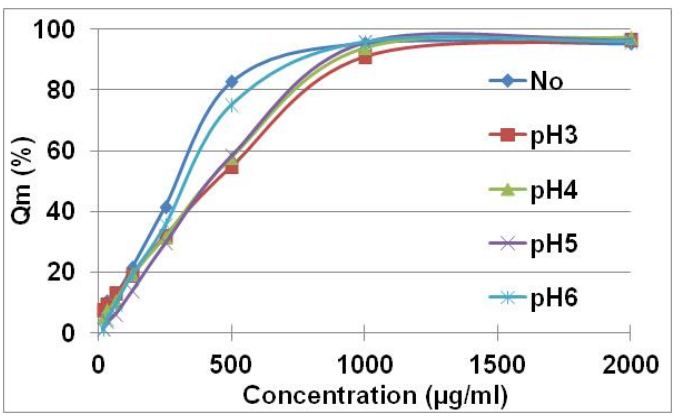

Figure 1. The initial antioxidant capacity of the colorant powders

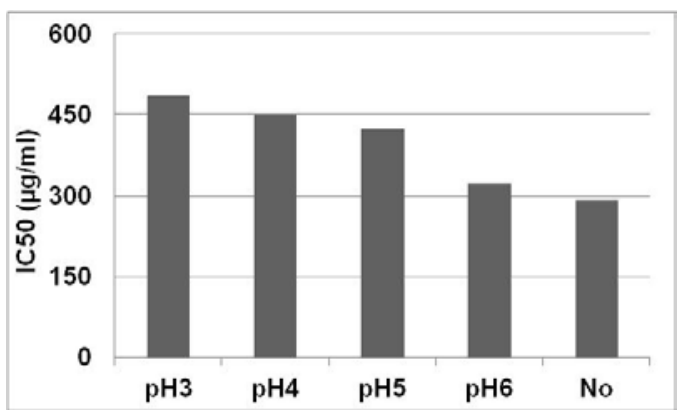

Figure 2. The antioxidant activity with IC50 value of the colorant powders

The antioxidant capacity of the colorant powders is shown in Fig. 1. Generally, the $\mathrm{pH}$ variation affected to the antioxidant capacity obviously. The percentage of radical inhibition was changed in different $\mathrm{pH}$ media clearly, but it seemed to be stable and about $90 \%$ in a concentration higher than $1000 \mu \mathrm{g} / \mathrm{mL}$. To evaluate and compare the antioxidant capacity of powders with acid citric, the IC50 value was determined and presented in Fig. 2. The highest scavenging activity was observed with the control powder (not adjusted the $\mathrm{pH}$ and marked as No) with IC50 value of $292.7 \mu \mathrm{g} / \mathrm{mL}$. That was followed by the colorant powder at $\mathrm{pH}$ of 6 with that of $320 \mu \mathrm{g} / \mathrm{mL}$. The $\mathrm{pH} 3$ powder exhibited the worst activity with IC50 value of $484 \mu \mathrm{g} / \mathrm{mL}$. The results showed that the $\mathrm{pH}$ condition affected to the antioxidant activity strongly. The higher acidic environment was, the lower antioxidant activity of 
the pigments was.

Generally, the stability of anthocyanins is influenced by temperature, concentration, radiation and $\mathrm{pH}$ conditions. In this work, the $\mathrm{pH}$ of the samples was altered before they were changed to powder form. In acidic media, four anthocyanin structures exist in equilibrium: flavylium cation, quinonoidal base, carbinol pseudobase and chalcone. The relative amounts of these structures at equilibrium vary with $\mathrm{pH}$ and anthocyanin structure [17]. At $\mathrm{pH} 3-6$, the red and stable flavylium cation form predominates, while at $\mathrm{pH} 6$ and above, it changes into the colorless carbinol pseudobase or chalcone forms and finally into the bluer and unstable quinonoidal base form [18]. The experimental conditions were set to simulate real storing condition.

Firstly, the effect of radiation condition to anthocyanin stability of the powders was investigated at ambient temperature $\left(30^{\circ} \mathrm{C}\right)$. The appearance color was not changed clearly. However, in the case of storing in the brown bottles or dark condition, the color seemed to be more stable. The results also indicated that the stability and antioxidant capacity of colorant during storage were not affected much when stored in the dark, but they changed by different $\mathrm{pH}$ condition (Fig. 3).

The control powder (non $\mathrm{pH}$ adjustment) had the worst anthocyanin stability of about $70 \%$ after 30 storing days. Besides, the $\mathrm{pH} 3$ sample still remained about $90 \%$ anthocyanin and it was the best stability (Fig. 3a). Polyanthocyanin value showed the quality of anthocyanins by calculating the ratio of anthocyanins in complex form. The $\mathrm{pH} 3$ powder also showed the best value with low polyanthocyanin index which was still lower than $20 \%$ after 30 days. Increasing $\mathrm{pH}$ condition led to decreasing quality of the anthocyanins by high index (Fig. 3b). In relatively strong acidic aqueous solutions ( $\mathrm{pH} 1 \pm 3$ ), all the anthocyanin 3glucosides occurred in the most intense reddish colours, typical for their flavylium forms. Anthocyanin stability and colour intensity then decreased towards neutrality $(\mathrm{pH} 5 \pm 7$ ), while there was a gradual bathochromic shift to more bluish colours [15].

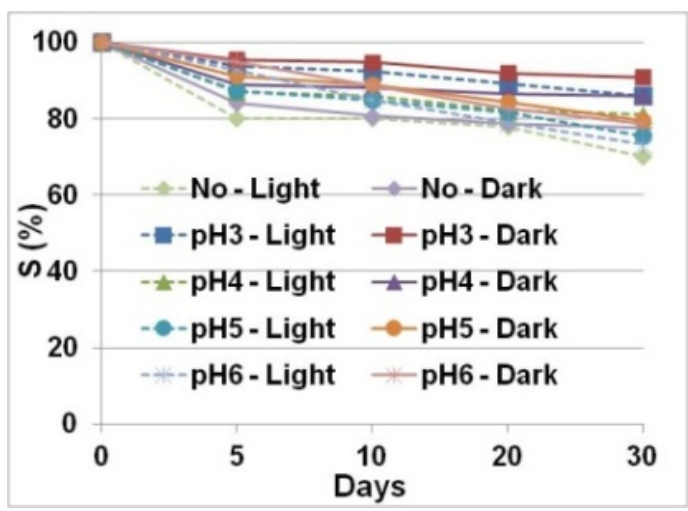

(a)

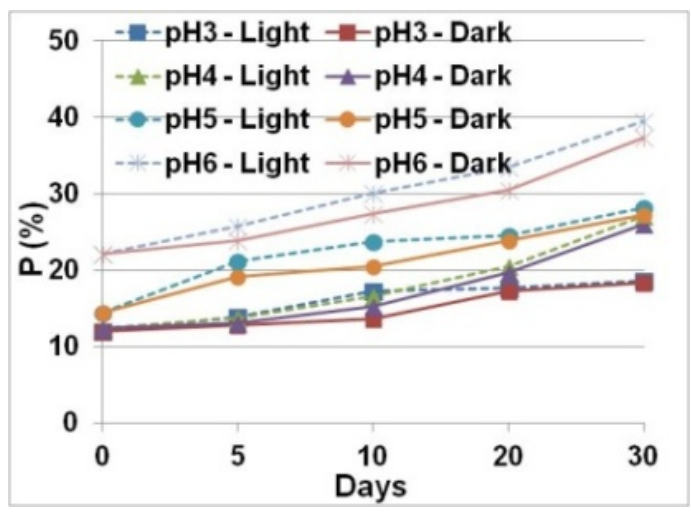

(b)

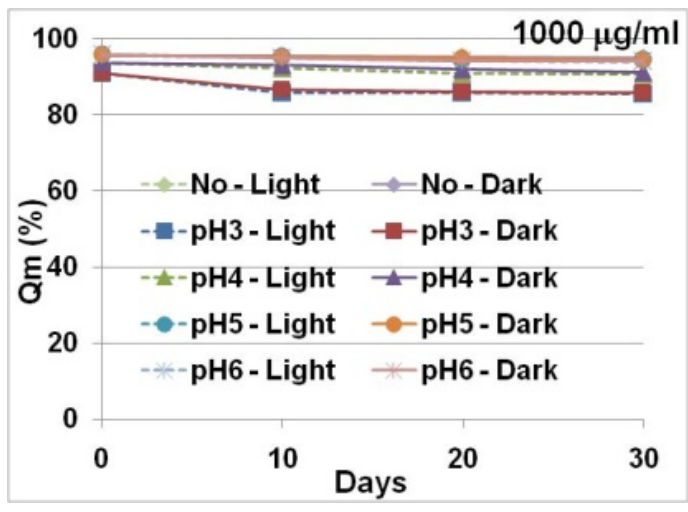

(c)

Figure 3. Effect of lighting on stability (a), polyanthocyanin values (b) and antioxidant capacity (c) of colorant powder during storage time

The antioxidant activity of the samples was evaluated by the inhibition percentage of the DPPH free radical at the sample concentration of $1000 \mu \mathrm{g} / \mathrm{mL}$ and $250 \mu \mathrm{g} / \mathrm{mL}$. By times, the antioxidant capacity slightly went down at both experimental concentrations and the change was exhibited at the sample concentration of 250 $\mu \mathrm{g} / \mathrm{mL}$ (Fig. 3c). The neutral $\mathrm{pH}$ also was the good 
media to preserve the antioxidant activity with high inhibition ratio. One again, no clear difference in antioxidant active was detected between light or dark storing condition. However, the dark (or brown) bottle might be better to remain their properties. Hence, all experiments in the next steps were carried out in the brown bottles.

Total anthocyanin content decreased by time and degradation rate strongly depended on the storage temperature. Increasing storage temperatures seemed to speed up the degradation rates (Fig. 4). At 10 and $30{ }^{\circ} \mathrm{C}$, the anthocyanin content of the samples was relatively stable, preserved about $80-95 \%$ after 30 days and the $\mathrm{pH} 3$ powders had the best stability. As predicted, degradation of anthocyanins was significantly accelerated at higher temperatures. Storing at 45 and $55{ }^{\circ} \mathrm{C}$, the remained anthocyanins was just about $15-60 \%$.

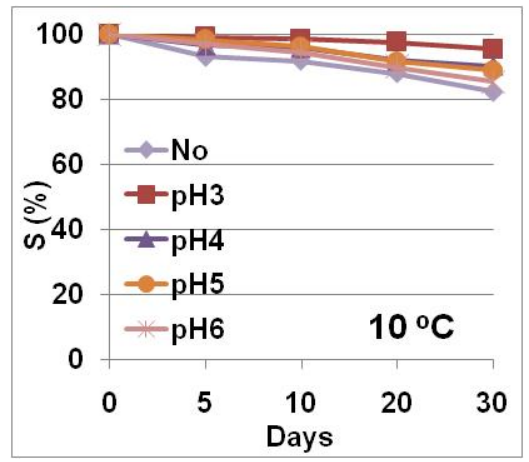

(a)

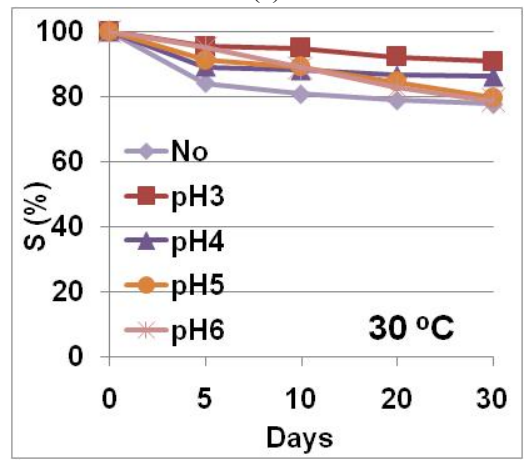

(b)

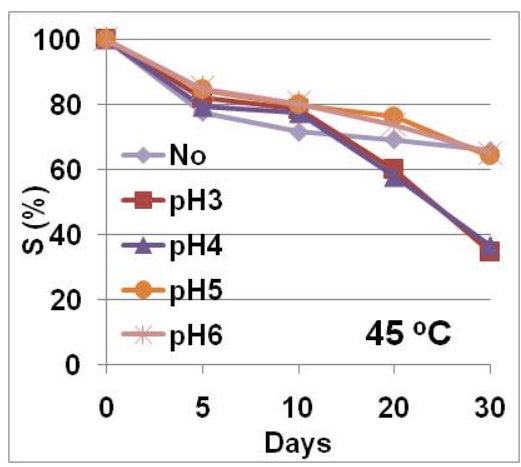

(c)

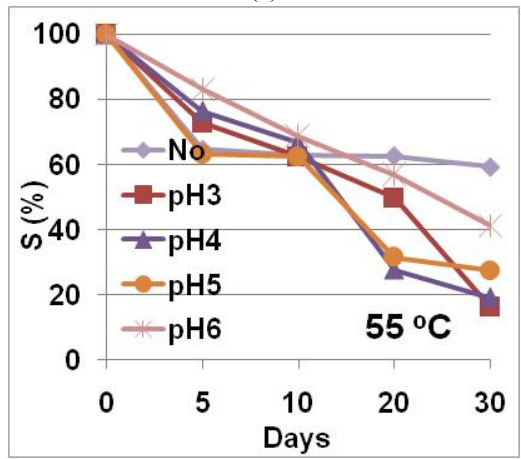

(d)

Figure 4. Effect of temperatures on stability of anthocyanin concentration during storage time

According to the experimental data, the polyanthocyanin index increased to show the denaturation of anthocyanins by polymerization and it also was affected by temperature. After 1 month, the index of $\mathrm{pH} 3$ powder alters in the range of $10-15 \%$ at storing temperature of 10 and $30^{\circ} \mathrm{C}$. In the case of higher temperature, that changed in the wider range of $10-50 \%$ (Fig. 5) which indicated a shelf life in the normal condition about 4 months in normal conditions. The high storage temperature and low $\mathrm{pH}$ of the powders were not a suitable condition to preserve the quality of the colorant powders. 


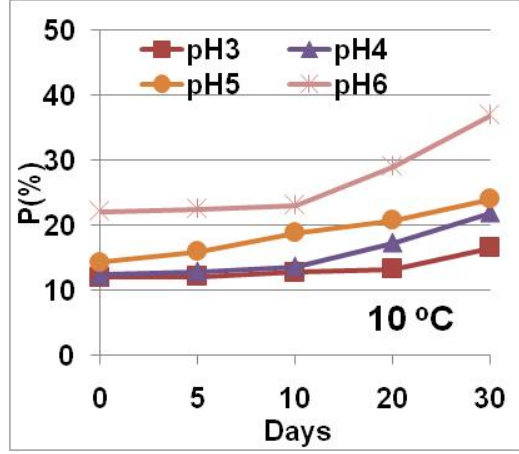

(a)

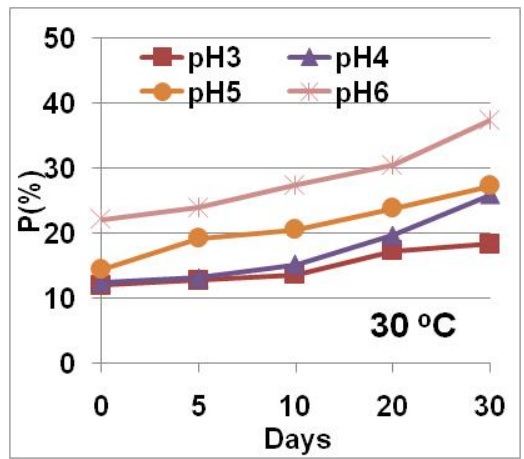

(b)

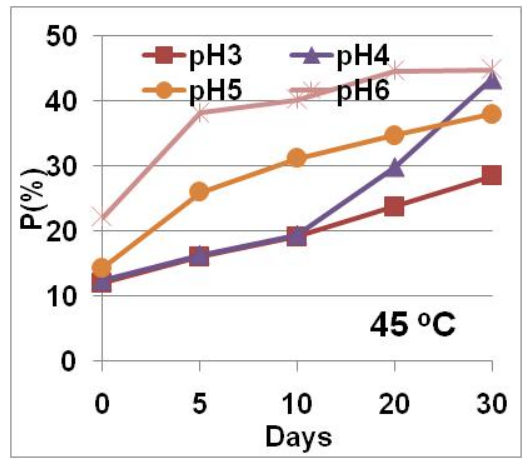

(c)

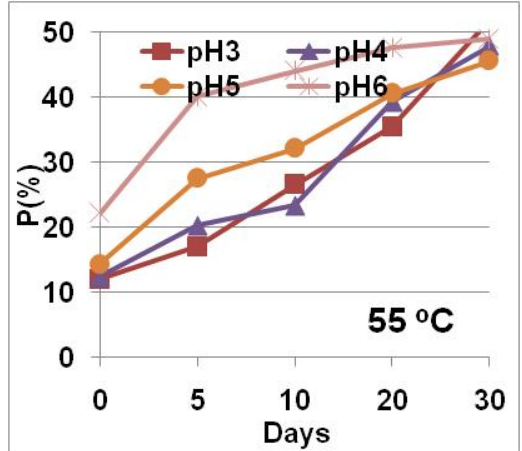

(d)

Figure 5. Effect of temperatures on stability of polyanthocyanin index during storage time

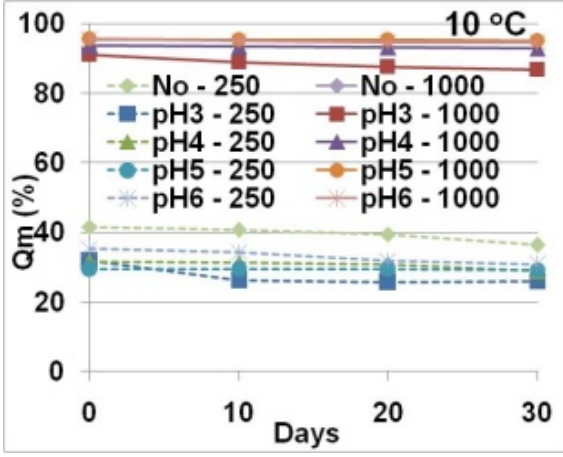

(a)

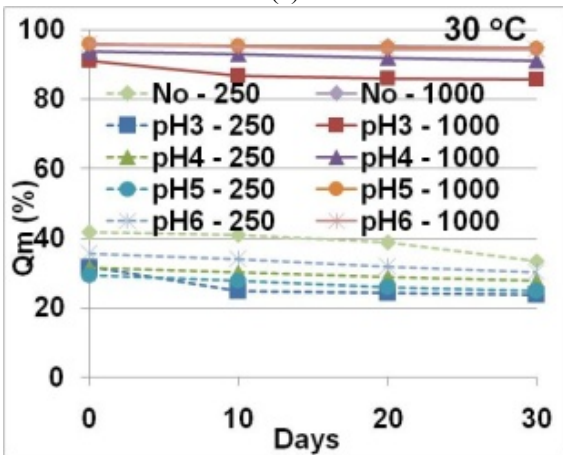

(b)

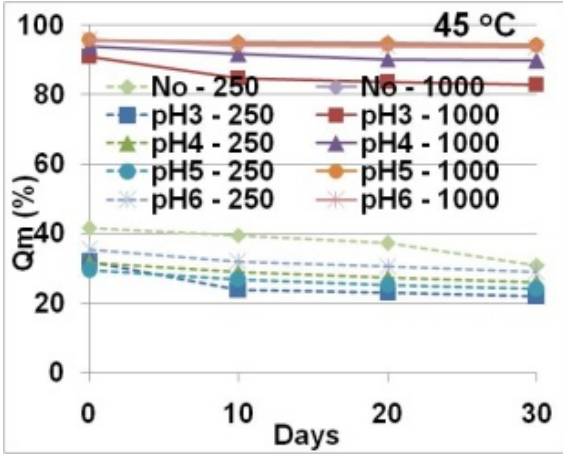

(c)

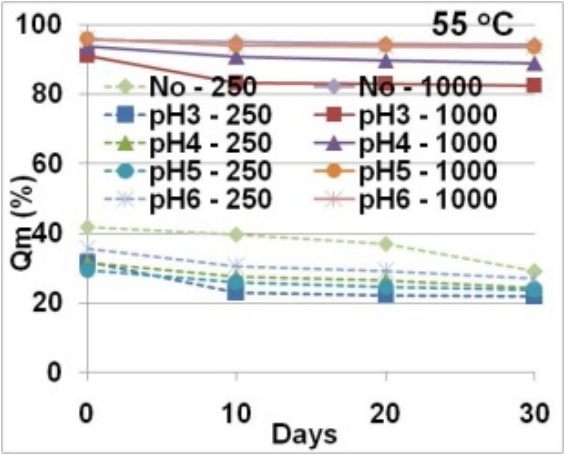

(d)

Figure 6. Effect of temperatures on stability of antioxidant capacity during storage time

All samples showed the radical scavenging activity of about $100 \%$ at the experimental concentration of $1000 \mu \mathrm{g} / \mathrm{mL}$ and no clear 
variation was detected. On the other hand, that at $250 \mu \mathrm{g} / \mathrm{mL}$ showed the effect of temperature and $\mathrm{pH}$ media to antioxidant activity obviously (Fig. 6). After 30 days, the radical inhibition of all powders was reduced in from about $40 \%$ to $20 \%$. No clear difference between the stability at a different temperature. However, the neutral samples still had the highest radical scavenging activity of about $30 \%$ after 30 days. The lower $\mathrm{pH}$ media of the samples still had the lower stability of antioxidant capacity. However, the result of evaluating antioxidative properties with the free radical DPPH of citric acid was very low. It could be said that the acidic media could preserve the colorant powder by protecting anthocyanins, but it reduced the biological property of the pigment.

\section{CONCLUSIONS.}

The purple colorants from Japanese purple sweet potato (Ipomoea batatas (L.) Poir) are easily prepared by available sources in Vietnam. They were satisfied all standards for food the colorants. In this work, the stability of the powder colorants was investigated and depended on many storing factors such as temperature and radiation conditions. Besides, the acidic media was not a good condition to preserve the antioxidant capacity. More studies should be carried out to increase their stability. However, the colorant powders are promising for applications, especially in the food products.

\section{TÀI LIỆU THAM KHẢO}

[1] T.C. Wallace, "Anthocyanins in Cardiovascular Disease". Advances in Nutrition: An International Review Journal, vol. 2, no. 1, pp. 1-7, 2011.

[2] N. Jia, et al., "Identification and Characterization of Anthocyanins by High-performance Liquid Chromatography-Electrospray Ionization-Mass Spectrometry in Herbaceous Peony Species", Journal of the American Society for Horticultural Science, vol. 133, no. 3, pp. 418-426, 2008.

[3] P.-J. Tsai, et al., "Anthocyanin and antioxidant capacity in Roselle (Hibiscus Sabdariffa L.) extract", Food Research International, vol. 35, no. 4, pp. 351-356, 2002.

[4] E. Prenesti, et al., "Antioxidant power quantification of decoction and cold infusions of Hibiscus sabdariffa flowers", Food Chemistry, vol. 100, no. 2, pp. 433-438, 2007.
[5] F.S. Hosseinian, et al., "Measurement of anthocyanins and other phytochemicals in purple wheat", Food Chemistry, vol. 109, no. 4, pp. 916-924, 2008.

[6] K. Duangmal, et al, "Roselle anthocyanins as a natural food colorant and improvement of its colour stability", in AIC 2004 Color and Paints - Proceedings of the Interim Meeting of the International Color Association, Porto, Alegre, Brazil, 2004, pp. 155-158.

[7] Lê Thị Hồng Nhan và cộng sự., "Khả năng kháng oxi hoá của chất màu từ đậu đen", Tạp chí Khoa học và Công nghệ,. vol. 50, no. 3A, pp. 14-19, 2012.

[8] G. Gradinaru, et al., "Thermal stability of Hibiscus sabdariffa L. anthocyanins in solution and in solid state: effects of copigmentation and glass transition", Food Chemistry, vol. 83, no. 3, pp. 423-436, 2003.

[9] Phan Nguyễn Quỳnh Anh, Lê Thị Hồng Nhan, "Nghiên cứu tách chất màu anthocyanin từ khoai lang tím Nhật (Ipomoea Batatas (L.) Poir)", Tạp chi Khoa học và Công nghẹ, vol. 51, no. 5B, pp. 172-177, 2013.

[10] A. Sokmen, et al., "The in vitro antioxidant and antimicrobial activities of the essential oil and methanol extracts of Achillea biebersteini Afan. (Asteraceae)", Phytother Res, vol. 18, no. 6, pp. 451-456, 2004.

[11] P., G.V., "Physico-chemical methods for analysis of phytochemical preparations and vegetal raw materials", Farm Zh, vol. 32, no. 1, pp. 36-44, 1977.

[12] D.S. Reid, et al., "A new method for accelerated shelflife prediction for frozen foods", J Sci Food Agric, vol. 83, no. 10, pp. 1018-1021, 2003.

[13] J. Lee, et al., "Determination of total monomeric anthocyanin pigment content of fruit juices, beverages, natural colorants, and wines by the $\mathrm{pH}$ differential method: collaborative study". J AOAC Int., vol. 88, no. 5, pp. 1269-1278, 2005.

[14] Huỳnh Thị Kim Cúc và cộng sự., "Xác định hàm lượng anthocyanin trong một số nguyên liệu rau quả bằng phương pháp $\mathrm{pH}$ vi sai", Tạp chí Khoa học và Công nghê, vol. 3, tr. 47-54, 2004.

[15] L. Cabrita, et al., "Colour and stability of the six common anthocyanidin 3-glucosides in aqueous solutions", Food Chemistry, vol. 68, no. 1, pp. 101-107, 2000.

[16] T. Fossen, et al., "Colour and stability of pure anthocyanins influenced by $\mathrm{pH}$ including the alkaline region", Food Chemistry, vol. 63, no. 4, pp. 435-440, 1998.

[17] B.A. Cevallos-Casals and L. Cisneros-Zevallos, "Stability of anthocyanin-based aqueous extracts of Andean purple corn and red-fleshed sweet potato compared to synthetic and natural colorants", Food Chemistry, vol. 86, no. 1, pp. 69-77, 2004.

[18] B. Caballero et al., Encyclopedia of Food and Health, Academic Press, USA, 2015.

Phan Nguyen Quynh Anh, received the Ph.D. degree in chemilcal engineering from $\mathrm{Ho}$ Chi Minh City University of Technology, VNU-HCM, 
in 2017. From 2010 until now, she is a researcher at University of Technology, VNU-HCM.
Le Thi Hong Nhan - a lecturer of Ho Chi Minh City University of Technology, VNU-HCM.

\section{Nghiên cứu độ bền của bột màu anthocyanin từ khoai lang tím Nhật (Ipomoea Batatas (L.) Poir)}

Phan Nguyễn Quỳnh Anh, Lê Thị Hồng Nhan

Tóm tắt - Nghiên cứu tập trung khảo sát độ bền của chất màu anthocyanin từ khoai lang tím Nhật (Ipomoea Batatas (L.) Poir) thu hoạch ở Vĩnh Long. Bột màu được hình thành từ dịch chiết được điều chỉnh về môi trường $\mathrm{pH}(6,5,4$ và 3$)$ trước khi chuyển về dạng bột. Bột thu được có màu đỏ tím, hàm lượng anthocyanin $32 \mathrm{mg} / \mathrm{g}$. Nồng độ ức chế gốc tự do IC50 của bột màu ở môi trường trung tính là 292,7 $\mu \mathrm{g} / \mathrm{mL}$, trong khi IC50 của bột màu pH3 là $484 \mu \mathrm{g} / \mathrm{mL}$, thể hiện hoạt tính kháng oxy hóa giảm khi tăng tính acid của môi trường. Độ bền màu sắc, hàm lượng anthocyanin, chỉ số polyanthocyanin và khả năng kháng oxy hóa được nghiên cứu phụ thuộc vào điều kiện bảo quản (nhiệt độ, ánh sáng) và môi trường $\mathrm{pH}$. Để tránh biến tính anthocyanin, bột màu phải bảo quản trong bóng tối ở nhiệt độ thấp $\left(10^{\circ} \mathrm{C}\right)$. Môi trường acid có thể bảo vệ anthocyanin của chất màu nhưng làm giảm hoạt tính sinh học của chất màu.

Tù $\boldsymbol{k h o ́ a ~ — ~ k h o a i ~ l a n g ~ t i ́ m , ~ a n t h o c y a n i n s , ~ đ o ̣ ̂ ~ b e ̂ ̀ n , ~ k h a ́ n g ~ o x y ~ h o ́ a . ~}$ 